Annals of Plant Sciences

\title{
Partial purification and characterisation of cytosolic Fructose-1, 6- bisphosphatase from Drymaria cordata
}

Niki Doma Sherpa ${ }^{1}$, Raksha Mukhia ${ }^{2}$, Dhani Raj Chhetri2*

${ }^{1}$ Department of Botany, Pakim Palatine College, Pakyong, Sikkim-737136, India

${ }^{2}$ Department of Botany, Sikkim University, $6^{\text {th }}$ Mile, Gangtok, Sikkim-737102, India.

Received: 2018-03-07; Accepted: 2018-03-21

\begin{abstract}
Drymaria cordata is an important ethnomedicinal plant from which many important secondary metabolites have been reported. Partial purification of the enzyme, fructose 1,6-bisphosphatase was carried out following the methods of homogenization, streptomycin sulphate precipitation, ammonium sulphate cut and molecular sieve chromatography through Bio-Gel A- $0.5 \mathrm{~m}$ column. Biochemical characterization experiments were performed by standard methods with the enzyme preparation as purified from the column. Cytosolic fructose 1,6-bisphosphatase from the leaves of Drymaria cordata was purified to about 27 -fold with $77 \%$ of recovery over homogenate fraction. The

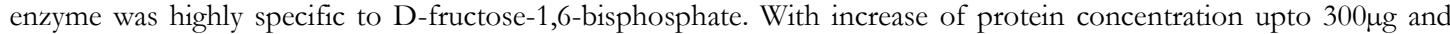
incubation time upto120 minutes, the enzyme activity increased linearly. The metal ions $\mathrm{Mg}^{2+}$ or $\mathrm{Mn}^{2+}$ strongly stimulated the enzyme activity on the other hand $\mathrm{Li}^{+}, \mathrm{Hg}^{2}+$ and $\mathrm{Zn}^{2+}$ were potent inhibitors. The $D$. cordata enzyme showed temperature maxima at $40^{\circ} \mathrm{C}$ while the optimum $\mathrm{pH}$ was at 8.0 . The $K_{\mathrm{m}}$ value of the enzyme for its substrate, Fructose 1,6-bisphosphate was $1.11 \mu \mathrm{M}$ proving its strong affinity.
\end{abstract}

Key words: Fructose 1,6-bisphosphatase, Fructose 1,6-bisphosphate, Drymaria cordata, protein purification, enzyme characterization.

\section{Introduction}

The enzyme Frutose 1,6 bisphophatase (FBPase; EC: 3.1.3.11) is related to gluconeogenesis and photosynthesis. It catalyzes the hydrolytic cleavage of fructose-1,6-bisphosphate to fructose-6phosphate and inorganic phosphate in the presence of divalent cations such as magnesium, manganese or zinc (Dzugaj, 2006). The FBPase reaction is a key regulatory step in gluconeogenesis and displays high negative free energy change (Bassham and Krause 1969) and permits endogenous glucose production from amino acids, glycerol or lactate. This enzyme is ubiquitous in photosynthetic organisms such as in bacteria (Gibson et al., 1990), blue- green algae (Crawford et al., 1984) and higher plants (Weeden and Buchanan, 1983).

In higher plants two FBPase isoforms have been identified: one being the cytosolic FBPase which participates in the synthesis of sucrose (Kelly et al., 1982) and the second enzyme is confined to the chloroplast which is essential in the photosynthethic carbon fixation into sugars (Chueca et al., 2002). The regulatory property of the chloroplast enzyme is distinctly different from the cytosolic or gluconeogenic FBPase (Lazoro et al., 1975).

The purification and characterization of Fructose-1, 6-bisphosphatase and its activity has been reported from plants as well as microbes. FBPase has been partially purified over 100 fold from blue green bacteria Anacystis nidulans (Udvardy 1982). The activity of FBPase was also detected from

${ }^{*}$ Corresponding Author:

Dhani Raj Chhetri,

Department of Botany, Sikkim University, 6th Mile,

Gangtok, Sikkim-737102, India.

E-mail: drchhetri@cus.ac.in fermenting and non-fermenting yeast grown in a sugar medium (Gancedo and Gancedo, 1971).

Cytosolic FBPase has been purified from spinach leaves where the enzyme is found to be a tetramer with a molecular weight of $130 \mathrm{kDa}$, paving a pathway for sucrose biosynthesis (Zimmermann et al., 1978). The cytosolic enzyme was purified and the regulatory propertiy of the same was examined from the mesophyll of leaves of Zea mays (Stitt and Heldt 1984). Cytosolic FBPase has also been purified from sugarbeet (Beta vulgaris L.) leaves (Khayat et al., 1993), endosperm of germinating castor oil seeds (Richard et al., 1995). Furthermore, the enzyme has also been purified and characterized from a recombinant pea plant (Jang et al., 2003), apple (Malus dometica) leaves (Zhou and Cheng, 2004) and the leaves of Ginkgo biloba (Yonzone et al., 2015).

Drymaria cordata (L.) Willd ex Roem. \& Schult. (D. cordata), locally known as "Abhijalo" in Sikkim is an annual herbaceous plant belonging to family Caryophyllaceae. This plant is utilized by the local people as one of the ingredients in many indigenous poly herbal formulations (Tejavathi and Indira 2012). This plant has been used traditionally as an appetizer, depurative, emollient, febrifuge, laxative and stimulant (Saklani and Jain 1994). A number of biologically active compounds have been isolated from the leaves of the plant including cyclopeptides, flavonoid glucosides (Ding et al., 1999, 2000),

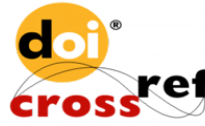


norditerpenes and norditerpene glycosides (Vargas et al., 1988). An alkaloid, drymaritin which exhibits anti-HIV properties against $\mathrm{H} 9$ lymphocytes has been isolated from Drymaria cordata (Hsieh et al., 2004). The present work is an attempt to investigate the FBPase enzymatic activity and its characterization from Drymaria cordata, since no work has so far been done on this aspect despite it being such a useful plant.

\section{Materials and Methods}

\section{Plant Material}

Mature leaves of $D$. cordata) were collected from fresh from around Gangtok, Sikkim $\left(27.33^{\circ} \mathrm{N}\right.$ $88.62^{\circ} \mathrm{E}$ ) between 6.00 and $7.00 \mathrm{AM}$ during JanuaryFebruary and brought to the lab for analysis. The plant was identified by the Botanical Survey of India, Eastern Regional Circle, Gangtok, India and the herbarium was deposited at the same organization. All the analytical work was carried out at between $0^{\circ} \mathrm{C}$ to $4^{\circ} \mathrm{C}$.

Partial Purification of gluconeogenic Fructose1, 6-bisphosphatase from $D$. cordata

The separated leaves of $D$. cordata was washed several times with cold distilled water followed by chilled 50mM Tris-HCl (pH-7.0) buffer containing $0.2 \mathrm{mM}$ 2-Mercaptoethanol (ME) and the partial purification of fructose-1,6-biphosphatase was done following the method outlined below:

\section{Homogenate}

$50 \mathrm{gms}$ of buffer washed leaf tissues obtained from $D$. cordata was homogenized with 3-volumes of $50 \mathrm{mM}$ Tris- $\mathrm{HCl}$ buffer ( $\mathrm{pH} 7.0$ ) containing $0.2 \mathrm{mM}$ ME. This crude homogenate was centrifuged at 1000 RPM for 2 minutes and the supernatant was collected which was designated as the homogenate fraction' and the total volume was recorded.

\section{Low Speed Supernatant}

The homogenate fraction was centrifuged at 10,000 RPM for 20 minutes in a Hermle - Z $32 \mathrm{HK}$ centrifuge. The pellet was discarded and the supernatant fraction was recovered from the centrifuge tube which was marked as 'low speed supernatant.'

\section{Streptomycin sulphate precipitation}

In order to remove contaminating nucleic acids in the form of precipitate, streptomycin sulphate powder was added gently to the low speed supernatant with constant stirring (by using a Remi magnetic stirrer) to a final concentration of $1 \%$ $(\mathrm{w} / \mathrm{v})$. After proper mixing, it was kept in icebucket for 20 minutes followed by a spin at 10,000 RPM for 15 minutes. The pellet was discarded and the supernatant fraction collected. This fraction was named as 'SS-fraction.'

\section{Ammonium sulphate fractionation}

The streptomycin sulphate treated fraction obtained from the previous step was made $0-30 \%$ saturated with ammonium sulphate $\left[\left(\mathrm{NH}_{4}\right)_{2} \mathrm{SO}_{4}\right]$ by adding requisite quantity $(17.6 \mathrm{~g}$ per $100 \mathrm{ml})$ solid ammonium sulphate slowly with constant stirring. The mixture was kept at $0^{\circ} \mathrm{C}$ for 15 minutes and centrifuged at 10,000 RPM for 20 minutes. The pellet was discarded and the supernatant fraction was made $30-70 \%$ saturated with $\left[\left(\mathrm{NH}_{4}\right)_{2} \mathrm{SO}_{4}\right]$ by adding requisite quantity $(27.3 \mathrm{~g}$ per $100 \mathrm{ml}$ ) salt slowly with constant stirring. The crude mixture was kept at $0^{\circ} \mathrm{C}$ for 15 minutes and then centrifuged at 10,000 RPM for 20 minutes. The pellet was collected which was dissolved in a minimal volume of $50 \mathrm{mM}$ Tris- $\mathrm{HCl}$ buffer ( $\mathrm{pH} 7.0$ ) having $0.2 \mathrm{mM}$ $\mathrm{ME}$ and dialyzed overnight against the same buffer (500 volumes). On completion of dialysis, the 30 $70 \%\left[\left(\mathrm{NH}_{4}\right)_{2} \mathrm{SO}_{4}\right]$ fraction was recovered from the dialysis bag. This purified extract was designated as 'A $\mathrm{A}_{2} \mathrm{~S}$-fraction.'

\section{Chromatography through BioGel A-0.5m} column

The dialyzed $\mathrm{A}_{2} \mathrm{~S}$-fraction obtained from the previous step was loaded onto a column of BioGel A-0.5m $(0.6 \times 8.0 \mathrm{~cm})$ pre-equilibrated with $50 \mathrm{mM}$ Tris- $\mathrm{HCl}$ buffer ( $\mathrm{pH}$ 7.0). Proteins were eluted from the column with the same buffer in fractions of 2.0 $\mathrm{ml}$ at a flow rate of 10 minutes per tube. 20 such fractions were collected. Fractions containing FBPase activity were pooled together and dialyzed against 500 volume of $50 \mathrm{mM}$ tris- $\mathrm{HCl}$ buffer $(\mathrm{pH}$ 7.0) containing $0.2 \mathrm{~mm}$ ME. This preparation (BioGel-fraction), was concentrated and used as the enzyme source for the experiments on characterization.

\section{Enzyme activity assay}

The FBPase activity was assayed by the procedure of Udvardy et al., (1982) with slight modification. The enzyme assay mixture contained $\mathrm{H}_{2} \mathrm{O}(620 \mu \mathrm{l})$,

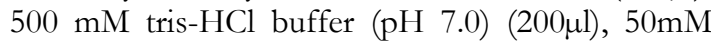
$\mathrm{MgCl}_{2}(100 \mu \mathrm{l}), 10 \mathrm{mM}$ Fructose 1,6-bisphosphate

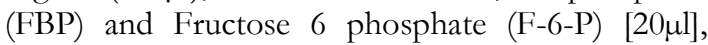
$10 \mathrm{mM}$ EDTA $(10 \mu \mathrm{l})$ and an appropriate aliquots of enzyme protein $(50 \mu \mathrm{l})$ making the total volume of $1.0 \mathrm{ml}$. After incubation for 60 minutes at $37^{\circ} \mathrm{C}$, the reaction was terminated by the addition of $200 \mu \mathrm{l}$ chilled 20\% trichloroacetic acid (TCA). To the deprotinized supernatant, $2.8 \mathrm{ml}$ of distilled $\mathrm{H}_{2} \mathrm{O}$ and $3 \mathrm{ml}$ of Pi-reagent was added followed by a second incubation at $37^{\circ} \mathrm{C}$ for $1 \mathrm{hr}$ for the oxidation of FBPase reaction product, D-fructose-6phosphate, with a subsequent release of inorganic phosphate.

The activity of the enzyme was determined by estimating the product-specific release of inorganic phosphate from D-fructose-6-phosphate by FBPase reaction. The amount of inorganic phosphate 
released from the FBPase reaction product was estimated by the method of Chen et al., (1956) and the protein was determined according the method of Bradford (1976) with BSA as a standard. The specific activity was defined as $\mu \mathrm{mol}$ Pi released $\mathrm{mg}$ protein $\mathrm{hr}^{-1}$. As 1 mole of fructose-6-phosphate contains 1 mole of inorganic phosphate, the total mole number of inorganic phosphate released was equal to the total mole number of fructose-6phosphate produced.

\section{Results and Discussion}

Although many ethnobotanical and pharmacological analyses have been previously reported from this plant species, no investigation has so far been made to check the activity of FBPase in this medicinal plant. The present work is an attempt to determine the occurrence of FBPase from $D$. cordata and to biochemically characterize the enzyme.

\section{Purification of Fructose-1,6-bisphosphatase from $D$. cordata}

The enzyme, FBPase was isolated and purified from the mature leaves of $D$. cordata. The summary on the purification of FBPase is given in table 1 . The protein resolved from BioGel A- $0.5 \mathrm{~m}$ column was taken for analysis. In the present study, an overall purification of the enzyme to about 27 -fold with about $77 \%$ recovery based on total activity was achieved. This recovery is quantitatively similar to that of castor-bean seedlings purified with Sephadex G-200 (Youle and Huang, 1976).

Table 1. Summary of partial purification of cytosolic Fructose-1,6- bisphosphatase from D. cordata leaves

\begin{tabular}{|c|c|c|c|c|c|}
\hline Purification step & $\begin{array}{l}\text { Protein } \\
\text { Content } \\
(\mathrm{mg} / \mathrm{ml})\end{array}$ & $\begin{array}{c}\text { Specific activity } \\
{[\mu \text { mol F-6-P produced }} \\
\left.\left(\mathrm{mg}^{-1}\right) \text { protein } \mathrm{h}^{-1}\right]\end{array}$ & $\begin{array}{c}\text { Total activity } \\
{[\mu \text { mol F-6-P produced }} \\
\left.\left(\mathrm{mg}^{-1}\right) \text { protein } \mathrm{h}^{-1}\right]\end{array}$ & $\begin{array}{c}\text { Recovery } \\
(\%)\end{array}$ & $\begin{array}{l}\text { Purification } \\
\text { (fold) }\end{array}$ \\
\hline Homogenate & $1.4 \pm 0.2$ & $10.7 \pm 0.6$ & $2250 \pm 68.3$ & $100 \pm 2.64$ & $1.0 \pm 0.01$ \\
\hline $10 \mathrm{~K}$-supernatant & $1.3 \pm 0.16$ & $11.0 \pm 0.8$ & $2059 \pm 49.2$ & $91.5 \pm 2.0$ & $1.03 \pm 0.3$ \\
\hline SS-fraction & $1.2 \pm 0.12$ & $13.3 \pm 0.9$ & $2138 \pm 58.4$ & $95.0 \pm 1.9$ & $1.2 \pm 0.1$ \\
\hline $\mathrm{A}_{2} \mathrm{~S}$-fraction & $1.1 \pm 0.1$ & $63.2 \pm 0.5$ & $695 \pm 13.3$ & $30.89 \pm 1.5$ & $5.9 \pm 0.2$ \\
\hline BioGel-fraction & $0.9 \pm 0.02$ & $297.4 \pm 4.8$ & $1739 \pm 39.6$ & $77.2 \pm 2.3$ & $27.35 \pm 0.3$ \\
\hline
\end{tabular}

(Values are Mean \pm SE, $n=3$ )

Characterization of the partially purified enzyme

The BioGel purified fraction of the enzyme was taken and the enzymatic characterization of cytosolic Fructose-1,6-bisphosphatase from Drymaria cordata was performed for the following parameters:

\section{Stability}

An important property of the D. cordata FBPase is the low stability of its catalytic activity. Stability of the ensyme varied with the enzyme preparation at different stages of purification. The low speed supernatant fraction remained active for 12-14 days when stored at $-20^{\circ} \mathrm{C}$. The $\left(\mathrm{NH}_{4}\right)_{2} \mathrm{SO}_{4}$ purified fraction recovered from dialysis bag maintained only about $70 \%$ of its activity upto 3-4 days when stored at identical temperature. Addition of an enzyme stabilizer 2-mercaptoethanol (ME) clearly increased the stability of the enzyme by 4-5 days. Similarly, the same enzyme purified from Selenastrum minutum is only stable for 2-5 days (Botha and Turpin, 1990). The stability of cytosolic D. cordata FBPase was very short in contrast to the same enzyme from other higher plants. The cytosolic
Enzyme purified from spinach leaves did not lose its activity upto 2 months of storage in $50 \%$ glycerol at $-20^{\circ} \mathrm{C}$ (Herzog et al., 1984). Similarly, at $-20^{\circ} \mathrm{C}$, the Anacystis nidulans FBPase could be stored, while maintaining its activity for several weeks (Udvardy et al., 1982).

\section{Substrate specificity}

The enzyme activity could be remarkably detected in the leaves of D. cordata and the cytosolic FBPase enzyme was highly specific for its substrate FBP. The partially purified $D$. cordata FBPase has been found to preferentially utilize FBP as substrate even in presence of other phosphorylated intermediates such as, Fructose-6-phosphate, D-glucose-6phosphate (G-6-P) and D-glucose-1-phosphate (G$1-\mathrm{P})$ at identical concentrations $(10 \mathrm{mM})$. When the specific substrate of the enzyme, FBP was not added to the reaction mixture, enzymatic synthesis of F-6-P could not be detected. However, this enzyme FBPase from D.a cordata could slightly utilize D-fructose-6-phosphate with about 17.14\% activity in comparison to the other phosphates as shown in table 2 . This may be a unique feature of D.cordata FBPase.

Table 2. Effect of some substrate isomers on cytosolic Fructose-1,6- bisphosphatase activity from $D$. cordata leaves.

\begin{tabular}{|c|c|c|c|}
\hline Compound & $\begin{array}{c}\text { Concentration } \\
(\mathrm{mM})\end{array}$ & $\begin{array}{c}\text { Specific activity } \\
{\left[\mu \text { mol F-6-P produced }\left(\mathrm{mg}^{-1}\right)\right.} \\
\left.\text { protein } \mathrm{h}^{-1}\right]\end{array}$ & Percent activity \\
\hline D-fructose-1,6-bisphosphate & 10 & $319.65 \pm 5.3$ & $100.00 \pm 2.0$ \\
\hline D-fructose-6-phosphate & 10 & $54.70 \pm 0.4$ & $17.14 \pm 0.8$ \\
\hline D-glucose-1-phosphate & 10 & $20.51 \pm 0.2$ & $6.42 \pm 0.2$ \\
\hline D-glucose-6-phosphate & 10 & $32.47 \pm 0.3$ & $10.17 \pm 0.6$ \\
\hline
\end{tabular}


Requirement for Drymaria cordata FBPase activity

$D$. cordata FBPase when assayed in presence of $500 \mathrm{mM}$ Tris- $\mathrm{HCl}$ buffer ( $\mathrm{pH} 7.5$ ), $50 \mathrm{mM} \mathrm{MgCl}$, $10 \mathrm{mM}$ FBP, $10 \mathrm{mM}$ F-6-P, $10 \mathrm{mM}$ EDTA with an appropriate protein aliquot was called the complete set and this reaction mixture recorded the maximum activity. The absence of the specific substrate i.e., FBP resulted in strong inhibition of the Drymaria cordata FBPase activity. About $76.82 \%$ activity was lost when Tris-HCl buffer was omitted from the complete reaction mixture. Deduction of $\mathrm{MgCl}_{2}$ and EDTA caused the reduction of enzyme activity by $34.4 \%$ and $47.41 \%$ respectively. Similarly the heat killed enzyme showed no such enzyme activity (Table 3). In contrast, the cytosolic FBPase from Ginkgo biloba leaves showed a reduction of enzyme activity by $58 \%, 68 \%$ and $50 \%$ by the deduction of tris buffer, $\mathrm{MgCl}_{2}$ and EDTA respectively from the reaction mixture (Yonzone et al., 2015).

\section{Progress of FBPase reaction with incubation} time

Incubation of Drymaria cordata FBPase was carried out for different time periods between the ranges of 0 min and 150 mins at an interval of 30 minutes under standard assay conditions (Table 4). It was observed that the reaction proceeds linearly upto 120 min with a slight increase in FBPase activity in each stage. However, Ginkgo biloba FBPase showed time linearity only upto 60 minutes under identical conditions Yonzone et al., 2015).

Table 3. Effect of composition of incubation medium on cytosolic Fructose-1,6- bisphosphatase activity from $D$. cordata leaves

\begin{tabular}{|c|c|c|}
\hline Condition & $\begin{array}{c}\text { Specific activity } \\
{\left[\mu \mathrm{mol} \mathrm{F-6-P} \text { produced }\left(\mathrm{mg}^{-1}\right) \text { protein } \mathrm{h}^{-1}\right]}\end{array}$ & Percent activity \\
\hline Complete set & $302.25 \pm 5.2$ & $100.00 \pm 2.0$ \\
\hline Without substrate (FBP) & $0.5 \pm 0.00$ & 0.00 \\
\hline Without buffer (Tris-HCl) & $198.29 \pm 3.9$ & $65.60 \pm 1.7$ \\
\hline Without $\mathrm{MgCl}_{2}$ & $70.08 \pm 0.5$ & $23.18 \pm 1.0$ \\
\hline Without EDTA & $158.97 \pm 3.6$ & $52.59 \pm 1.2$ \\
\hline Heat killed enzyme & $0.5 \pm 0.00$ & 0.00 \\
\hline
\end{tabular}

(Values are Mean \pm SE, $\mathrm{n}=3$ )

Table 4. Effect of different incubation time on cytosolic Fructose-1,6- bisphosphatase activity from $D$. cordata leaves

\begin{tabular}{ccc}
\hline Sl. No. & $\begin{array}{c}\text { Reaction incubation time } \\
\text { (minutes) }\end{array}$ & $\begin{array}{c}\text { FBPase activity } \\
\left(\mu \mathrm{mol} \text { F-6-P produced } \mathbf{~ m}^{-1} \text { protein }^{-\mathbf{1}}\right)\end{array}$ \\
\hline 1. & 0 & $220.51 \pm 4.2$ \\
2. & 30 & $307.69 \pm 5.2$ \\
3. & 60 & $312.65 \pm 5.3$ \\
4. & 90 & $357.26 \pm 5.7$ \\
5. & 120 & $379.48 \pm 5.9$ \\
6. & 150 & $366.25 \pm 3.6$ \\
\hline
\end{tabular}

(Values are Mean $\pm \mathrm{SE}, \mathrm{n}=3$ )

Table 5. Effect of varied enzyme concentration on Fructose-1,6- bisphosphatase activity from $D$. cordata leaves

\begin{tabular}{ccc}
\hline S1. No. & $\begin{array}{c}\text { Enzyme protein concentration } \\
\text { in the reaction mixture }(\boldsymbol{\mu g})\end{array}$ & $\begin{array}{c}\text { Specific activity } \\
{\left[\boldsymbol{\mu} \text { mol F-6-P } \text { produced }\left(\mathbf{m g}^{-1}\right) \text { protein }^{-1} \text { ] }\right.}\end{array}$ \\
\hline 1 & 0 & $59.82 \pm 0.4$ \\
2 & 50 & $220.51 \pm 4.2$ \\
3 & 100 & $263.24 \pm 4.5$ \\
4 & 150 & $302.24 \pm 5.2$ \\
5 & 200 & $319.65 \pm 5.3$ \\
6 & 250 & $329.91 \pm 5.5$ \\
7 & 300 & $384.61 \pm 6.0$ \\
8 & 350 & $357.26 \pm 5.7$ \\
9 & 400 & $369.23 \pm 5.8$ \\
\hline
\end{tabular}

(Values are Mean $\pm \mathrm{SE}, \mathrm{n}=3$ )

Progress of FBPase reaction with respect to protein concentration

Using increasing concentration of Drymaria cordata enzyme protein from from $0-400 \mu g$, Fructose-1,6bisphosphatase assay was carried out under optimal conditions. It has been revealed that the Drymaria cordata FBPase activity has increased linearly with the increase of protein concentration up to $300 \mu \mathrm{g}$ (Table 5), whereas the activity of Ginkgo biloba enzyme) increased upto a concentration of $400 \mu \mathrm{g}$
(Yonzone et al., 2015) while a related enzyme, inositol synthase from Lunularia cruciata showed similar value i.e., increased upto a concentration of

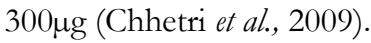

FBPase activity at different incubation temperature

In order to find out the relative enzyme activity as a function of incubation temperature, FBPase from $D$. cordata was incubated separately for one hour at 
temperature between the ranges of $0^{\circ} \mathrm{C}$ and $60^{\circ} \mathrm{C}$ at an interval of ten degrees each in presence of the standard assay mixture. Results plotted in fig.1 show that the activity of the enzyme was least at $0^{\circ} \mathrm{C}$, $10^{\circ} \mathrm{C}$ and $60^{\circ} \mathrm{C}$. However, the enzyme was remarkably active between the temperature ranges of $20^{\circ} \mathrm{C}$ and $50^{\circ} \mathrm{C}$ with the maximum activity encountered at $40^{\circ} \mathrm{C}$. However, the cytosolic enzyme from spinach and pea leaves showed a low linear activity when stored at $0^{\circ} \mathrm{C}-120^{\circ} \mathrm{C}$ (Weeden and Buchanan, 1983). Cytosolic FBPase from higher plants generally showed temperature maxima near about $30^{\circ} \mathrm{C}$.

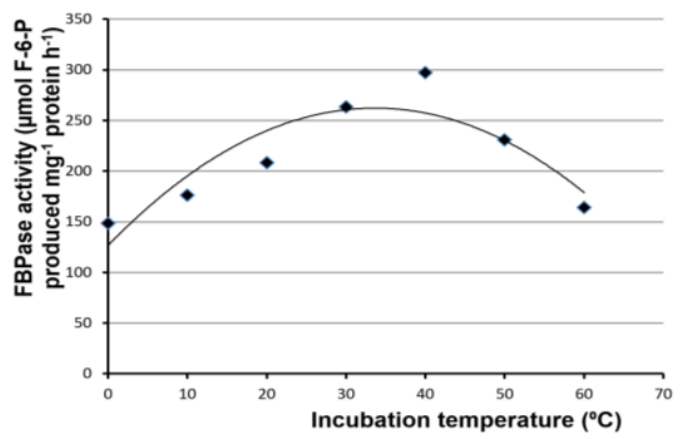

Figure 1. Effect of different incubation temperatures on Fructose-1,6-bisphosphatase activity from $D$. cordata leaves (enzyme activity defined as $\mu \mathrm{mol}$ F-6-P produced $\mathrm{mg}^{-1}$ protein $\mathrm{h}^{-1}$ )

FBPase enzyme activity at different $\mathrm{pH}$

From the data represented in fig.2, it becomes clear that the FBPase enzyme activity was appreciably increased at a narrow $\mathrm{pH}$ range from 6.5 to 8.5. The $D$. cordata FBPase exhibited optimum activity at a $\mathrm{pH}$ range of 7.0-8.0 with maximum at $\mathrm{pH}$ 8.0. The castor bean seedling FBPase also showed optimal activity between $\mathrm{pH} 7.0$ and 8.5 , but the activity was 50 times greater in $\mathrm{pH} 8.5$ as compared to that at $\mathrm{pH} 7.0$ (Youle and Huang, 1976). Similar pH optimum of 8.0 was found in the enzyme from Selenastrum minutum which changes to 8.5 when DTT was removed from the reaction mixture (Botha and Turpin, 1990).

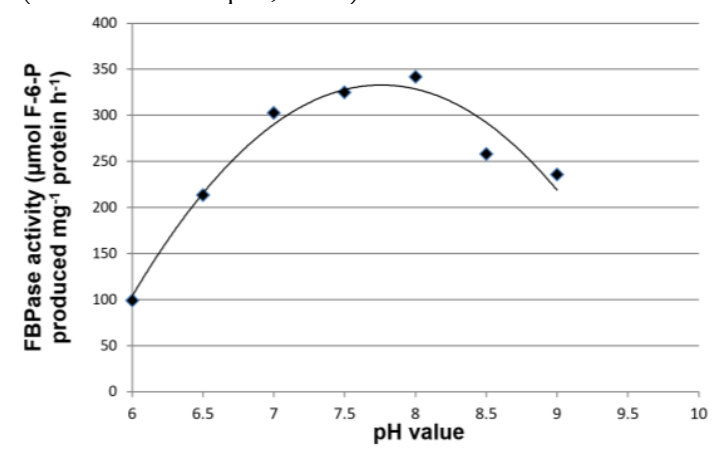

Figure-2: Effect of different $\mathrm{pH}$ on cytosolic Fructose-1,6-bisphosphatase activity from $D$. cordata leaves (enzyme activity defined as $\mu \mathrm{mol}$ F-6-P produced $\mathrm{mg}^{-1}$ protein $\mathrm{h}^{-1}$ )

The $\mathrm{pH}$ maxima of 8.0 for $D$. cordata FBPase activity was quite similar to the $\mathrm{pH}$ optima towards the alkaline range shown by the same enzyme in other plants viz., $\mathrm{pH} 8.0$ in spinach leaves (Zimmermann et al., 1978) and S. cerevisiae (Funyama et al., 1979). Similarly, G. biloba showed a $\mathrm{pH}$ maximum of 7.5-8.0 (Yonzone et al., 2015). In contrast, the $\mathrm{pH}$ optimum was found to be towards neutral in FBPase extracted from different fatty seeds (Youle and Huang, 1976) while the same was found to be 7.5 in apple leaves (Zhou and Cheng 2004).

\section{Effect of monovalent and divalent cations}

Effect of some monovalent cations and divalent cations on $D$. cordata FBPase activity was studied using variable concentration $(0-10 \mathrm{mM})$ of chloride salts of $\mathrm{K}^{+}, \mathrm{Na}^{+}, \mathrm{NH}^{4+}, \mathrm{Li}^{+}, \mathrm{Mg}^{2+}, \mathrm{Mn}^{2+}, \mathrm{Zn}^{2+}$, $\mathrm{Hg}^{2+}$. The partially purified of $D$. cordata FBPase was incubated in presence of the variable concentration of individual metal ions mentioned, to the usual assay components and keeping one control set without adding any such cation. Results of such experiments have been shown in table 6 . Among the monovalent cations tested, $\mathrm{K}^{+}, \mathrm{Na}^{+}$and $\mathrm{NH}_{4}{ }^{+}$slightly enhanced FBPase activity at least upto $10 \mathrm{mM}$, on the contrary $\mathrm{Li}^{+}$was a very effective inhibitor of this enzyme. Earlier studies on Purococcus furiosus had shown that monovalent cations $\mathrm{K}^{+}$showed a slight stimulating effect on the enzyme reaction, whereas $\mathrm{Li}^{+}$inhibited the activity (Verhees et al., 2002).

Of the divalent cations, cytosolic FBPase from $D$. cordata leaves has shown an absolute requirement for $\mathrm{Mg}^{2+}$ or $\mathrm{Mn}^{2+}$ which has a strong stimulatory effect to the enzyme activity. On the other hand, $\mathrm{Zn}^{+}, \mathrm{Hg}^{+}$and $\mathrm{Cd}^{+}$salts were found to act as potent inhibitors of D. cordata FBPase activity. Similarly, in Magnifera indica FBPase activity was inhibited by $\mathrm{Zn}^{+2}$ and no activity was detected in the absence of $\mathrm{Mg}^{+2}$ (Kumar and Selvaraj 1990). In apple leaves, $\mathrm{Na}^{2+}, \mathrm{Ca}^{2+}, \mathrm{Cu}^{2+}, \mathrm{Zn}^{2+}$ and $\mathrm{Hg}^{2+}$ inhibited the enzyme activity while $\mathrm{Mn}^{2+}$ synergsistically stimulated the activity of the FBPase enzyme (Zhou and Cheng, 2004). Gingko biloba FBPase showed a similar characteristic where the divalent cations, $\mathrm{Mg}^{+2}$ and $\mathrm{Mn}^{+2}$ were strongly stimulatory while $\mathrm{Zn}^{+2}$ and $\mathrm{Li}^{+1}$ were strongly inhibitory to the FBPase activity (Yonzone et al., 2015). The strong inhibition due to heavy metals suggests that one or more free sulphydryl groups are present within the active site of the enzyme (Chhetri et al., 2006). 
Table 6. Effect of monovalent and divalent cations on cytosolic Fructose-1,6-bisphosphatase activity from D. cordata leaves

\begin{tabular}{lcccccccc}
\hline \multirow{2}{*}{$\begin{array}{c}\text { Cation concentration } \\
(\mathbf{m M})\end{array}$} & \multicolumn{7}{c}{ Specific activity $\left(\boldsymbol{\mu m o l ~ F - 6 - P}\right.$ produced $\left.\mathbf{~ g}^{-1} \mathbf{p r o t e i n ~}^{\mathbf{- 1}}\right)$} \\
\cline { 2 - 8 } & $\mathbf{K}^{+}$ & $\mathbf{N a}^{+}$ & $\mathbf{L i}^{+}$ & $\mathbf{N H}_{4}{ }^{+}$ & $\mathbf{M g}^{\mathbf{2 +}}$ & $\mathbf{M n}^{2+}$ & $\mathbf{Z n}^{2+}$ & $\mathbf{H g}^{\mathbf{2 +}}$ \\
\hline 0 & $70 \pm 1.5$ & $70 \pm 1.5$ & $70 \pm 1.5$ & $70 \pm 1.5$ & $70 \pm 1.5$ & $70 \pm 1.5$ & $70 \pm 1.5$ & $70 \pm 1.5$ \\
2 & $92 \pm 0.7$ & $50 \pm 0.3$ & $67 \pm 1.0$ & $82 \pm 0.6$ & $191 \pm 1.9$ & $99 \pm 0.8$ & $64 \pm 1.5$ & $64 \pm 2.0$ \\
4 & $109 \pm 1.0$ & $104 \pm 0.9$ & $42 \pm 0.5$ & $99 \pm 0.8$ & $213 \pm 2.2$ & $109 \pm 1.0$ & $54 \pm 1.0$ & $47 \pm 1.1$ \\
6 & $114 \pm 1.1$ & $126 \pm 1.2$ & $37 \pm 0.7$ & $105 \pm 0.9$ & $225 \pm 2.6$ & $186 \pm 1.8$ & $49 \pm 0.2$ & $32 \pm 0.8$ \\
8 & $126 \pm 1.2$ & $120 \pm 1.2$ & $32 \pm 0.2$ & $109 \pm 1.0$ & $235 \pm 2.9$ & $186 \pm 1.8$ & $40 \pm 0.3$ & $28 \pm 0.7$ \\
10 & $160 \pm 1.6$ & $126 \pm 1.2$ & $26 \pm 0.4$ & $131 \pm 1.3$ & $241 \pm 3.1$ & $198 \pm 1.9$ & $29 \pm 0.1$ & $14 \pm 0.5$ \\
\hline
\end{tabular}

Values are Mean $\pm \mathrm{SE}, \mathrm{n}=3$ )

\section{Effect of EDTA}

The catalytic activity of the FBPase enzyme of $D$. cordata was measured by using different concentration of EDTA in the ranges of $0-100 \mathrm{mM}$. As evident from the result described in fig. 3 EDTA activated the enzyme activity up to concentration $40 \mathrm{mM}$ and then as the concentration increased $(60-$ $100 \mathrm{mM}$ ) it inhibited the activity of FBPase. Similar effect was observed in Gingko biloba where EDTA was stimulatory to cytosolic FBPase activity upto $30 \mathrm{mM}$, beyond which it seemed to be toxic. Inhibition by EDTA was also a characteristic feature of FBPase from Acer pseudoplantanus (Scala and Semersky, 1971).

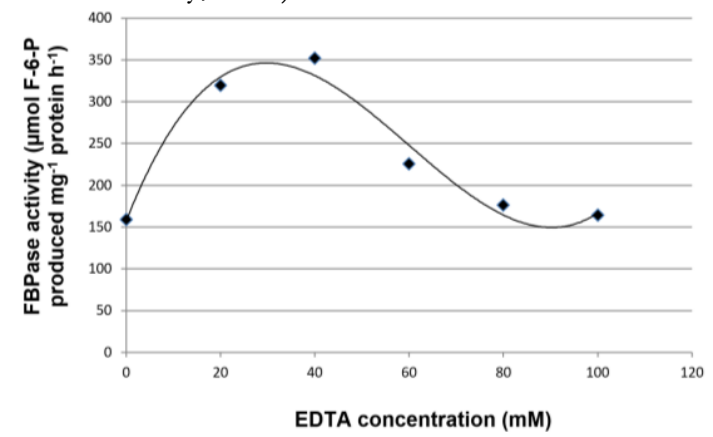

Figure 3. Effect of varied EDTA concentration on cytosolic Fructose-1,6-bisphosphatase activity from $D$. cordata (enzyme activity defined as $\mu$ mol F-6-P produced $\mathrm{mg}^{-1}$ protein $\left.\mathrm{h}^{-1}\right)$

\section{Determination of $K_{\mathrm{m}}$ value:}

The activity of ammonium sulphate purified $D$. cordata FBPase was found to increase linearly with respect to the increase in the concentration of FBP ranging from $0-10 \mathrm{mM}$ with an interval of $2 \mathrm{mM}$ each. The enzyme activity increased linearly upto $10 \mathrm{mM}$. The average $K_{\mathrm{m}}$ value for $D$. cordata cytosolic FBPase for its substrate FBP was $1.11 \mu \mathrm{M}$ which was nearer to that of the cytoplasmic FBPase from Gingko biloba leaves having a $K_{\mathrm{m}}$ value of $1.86 \mu \mathrm{M}$ (Yonzone et al., 2015) as determined in accordance with the rate equation of Michaelis-Menten (Fig. 4). In contrast, the $K_{\mathrm{m}}$ value was quite high for the same substrate for the enzyme obtained from other species e.g., $3 \mu \mathrm{M}$ from spinach leaves (Habron et al., 1981); 3.1 $\mu \mathrm{M}$ from apple leaf (Zhou and Cheng, 2004) and $16.7 \mu \mathrm{M}$ from Vigna radiata (Lal et al., 2005)

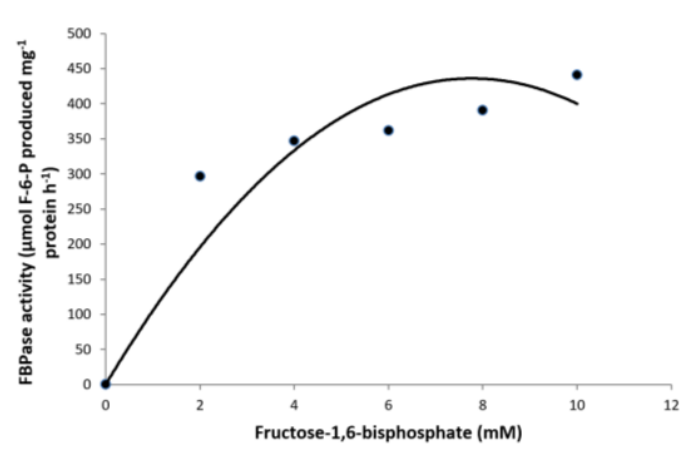

Figure 4. Effect of varied substrate (FBP) concentration on cytosolic Fructose-1,6bisphosphatase activity from $D$. cordata (enzyme activity defined as $\mu \mathrm{mol}$ F-6-P produced $\mathrm{mg}^{-1}$ protein $\mathrm{h}^{-1}$ )

\section{Conclusion}

The present work describes the occurrence of Fructose 1,6-bisphosphatase, in Drymaria cordata, its partial purification and biochemical characterization. This study is important since it provided an understanding of the metabolic regulation and characterization of the enzyme that may pave the way for its application in science and industry in the days to come.

\section{Conflict of interest statement}

The authors declare that there is no conflict of interest regarding the publication of this article

\section{References}

1. Bassham JA, GH Krause, Free energy changes and metabolic regulation in steady- state photosynthetic carbon reduction. Biochim Biophys Acta 1969; 189 (2): 207-221.

2. Botha FC, DH Turpin, Fructose 1,6-bisphosphatase in the green algae Selenastrum minutum. Plant Physiol 1990; 93(4): 1460-1465.

3. Bradford MM, Quantitation of microgram quantities of protein utilizing the principle of protein-dye binding Anal Biochem, 1976, 72: 248-254

4. Chen RS, Toribara TY, Warner H, Microdetermination of phosphorous. Anal Biochem 1956; 28: 1756-1758.

5. Chhetri DR, AK Mukherjee, J Adhikari, Biosynthesis of myo-inositol in pteridophytes; Isolation and characterization of L-myo; Inositol-1phosphate synthase from Diplopterygium glaucum. Braz J Plant Physiology 2006; 18 (2): 291-298. 
6. Chhetri DR, S Yonzone, S Tamang, AK Mukherjee, L-myo-Inositol-1-phosphate synthase from bryophytes: purification and characterization of the enzyme from Lunularia cruciata (L.) Dum. Braz J Plant Physiol 2009, 21 (3): 243-250.

7. Chueca A, M Sahrawy, EA Pagano, JL Gorge, Chloroplast fructose-1,6-bisphosphatase: Structure and function. Photosyn Res 2002, 74 (3): 235-249.

8. Crawford NA, CW Sutton, TC Johnson, DC Carlson, BB Buchanan, Contrasting modes of photosynthetic enzyme regulation in oxygenic and anoxygenic prokaryotes. Arch Microbiol 1984, 139(23): $124-129$.

9. Ding Z, J Zhou, $\mathrm{N}$ Tan, $\mathrm{R}$ Teng, Two new cyclicpeptides from Drymaria diandra. Planta. Med 2000, 66: 368-388.

10. Ding Z, J Zhou, Tan, A novel flavonoid glycoside from Drymaria diandra. Planta Med 1999, 65: 578-579.

11. Dzugaj A, Localization and regulation of muscle fructose-1,6-bisphosphatase, the key enzyme of glyconeogenesis. Adv Ensyme Regul 2006; 46: 51-71.

12. Funayama S, J Molano, C Gancedo, Purification and properties of D-fructose 1,6- bisphosphatase from Saccharomyces cerevisiae. Arch Biochem Biophys 1979, 197: 170-177.

13. Gancedo JM, C Gancedo, Fructose 1,6 diphosphatase, phosphofrutokinase and glucose-6phosphate dehydrogenase from fermenting and nonfermenting yeast. Arch Microbiol 1971, 76:132-138.

14. Gibson JL, JH Chen, PA Tower, FR Tabita, The form II fructose-1,6-bisphosphatase and phosphoribulokinase genes form part of a large operon in Rhodobacter sphaeroides Primary structure and insertional mutagenesis analysis. Biochemistry 1990, 29: 8085-8093.

15. Habron S, C Foyer, DA Walker, The purification and properties of sucrose phosphate synthase from spinach leaves: the involvement of this enzyme and fructose bisphosphatase in the regulation of sucrose biosynthesis. Arch Biochem Biophys 1981; 212: 237 246.

16. Herzog B, M Stitt, HW Heldt, Control of photosynthetic sucrose synthesis by Fructose 2,6bisphosphate. Plant Physiol 1984; 7: 561-565.

17. Horecker BL, Melloni E, Pontremoll S, Fructose 1,6- bisphosphatase: properties of the neutral enzyme and its modification by proteolytic enzymes. Advanced Enaymology 1975; 42: 193-226.

18. Hsieh PW, FR Chang, KH Lee, TL Hwang, SM Chang, YCA Wu, New anti-HIV alkaloid, Drymaritin, and a new glycoside flavonoid, diandraflavone, from Drymaria diandra J Nat Prod 2004, 67: 1175-1177.
19. Jang HK, SW Lee, YH Lee, TR Hahn, Purification and characterization of a recombinant pea cytoplasmic fructose-1,6-bisphosphatase. Protein Expression \& Purification 2003, 28: 42-48.

20. Kelly GJ, G Zimmermann, E Latzko, Fructose bisphosphatase from spinach leaf chloroplast and cytoplasm. Methods Ensym 1982, 90: 371-378.

21. Khayat E, C Harn, J Daie, Purification and LightDependent Molecular Modulation of the Cytosolic Fructose-1,6-Bisphosphatse in Sugarbeet Leaves. Plant Physiology, 1993, 101: 57-64.

22. Kumar R, Y Selvaraj, Fructose-1,6-bisphosphatase in ripening mango (Mangifera indica L.) fruit Ind J Expt Biol 1990, 28: 284-286.

23. Lal A, WC Plaxton, AM Kayastha, Purification and charactization of an allosteric fructose-1,6bisphosphate aldolase from germinating mung beans (Vigna radiata). Phytochemistry 2005, 66: 968-974.

24. Lazaro JJ, A Chueca, JL George, F Mayor, Properties of spinach chloroplast fructose 1,6bisphosphatase. Phytochemistry 1975, 14: 2579-2583.

25. Richard JH, CP William, Effect of polyethylene glycol on the activity, intrinsic fluorescence, and oligomeric structure of castor seed cytosolic fructose-1,6-bisphosphatase. FEBS letters, 1995, 368(3): 559-562.

26. Saklani A, SK Jain, Cross cultural ethnobotany of North East India, New Delhi, Deep publishers, 1994, 97

27. Scala J, FE Semersky, An induced fructose 1, 6 bisphosphatase from cultured cells of Acer pseudoplaltanus (English sycamore). Phytochemistry 1971, 10: 567-570.

28. Stitt M, HW Heldt, Control of photosynthetic sucrose synthesis by fructose-2,6-bisphophate. Planta 1984, 164: 179-188.

29. Tejavathi $\mathrm{DH}, \mathrm{MN}$ Indira, In vitro regeneration of multiple shoots from the nodal explants of Drymaria cordata (L.) Willd. Ex. Roem. and Schult. The Bioscan 2012, 7(1): 81-84.

30. Udvardy J, MM Godeh, Farkas, Regulatory properties of fructose 1, 6 bisphosphatase from Cyanobacterium, Anacystis nidulans. J Bacteriol, 1982, 151: 203-208

31. Vargas D, XA Dominguez, KA Askar, M Gutierrez, K Hostettmann, Phytochemistry 1988; 27: 1532-1434.

32. Verhees CH, J Ackerboom E Schiltz. WM deVos, J VanderOost, Molecular and biochemical characterization of a distinct type of fructose 1,6 bisphosphatase from Pyrococcus furiosus. I Bacteriol, 2002, 184(12): 3401-3405.

33. Weeden NF, BB Buchanan, Leaf cytosolic Fructose1,6-bisphosphatase, a potential target site in low temperature stress. Plant Physiol, 1983, 72:259-261. 
34. Yonzone S, S Jha, DR Chhetri, Gluconeogenic Fructose 1,6-bisphosphatase from Ginkgo biloba L: Isolation and characterization. Annals of Plant Sciences, 2015, 4 (05): 1116-1122.

35. Youle RJ, AHC Huang, Development and properties of fructose 1,6-bisphosphatase in the endosperm of castor bean seedlings. Biochem J 1976, 154: 647-652.

36. Zhou R, L Cheng, Biochemical characterization of cytosolic fructose 1, 6 bisphosphatase from apple
(Malus domestica) leaves. Plant Physiol 2004; 45 (7): 879-886.

37. Zimmermann GG, J Kelly, Latzko, Purification and properties of spinach leaf cytoplasmic fructose 1, 6 bisphosphatase. J Biol Chem 1978, 253: 5952-5956.

\section{Cite this article as:}

Niki Doma Sherpa, Raksha Mukhia, Dhani Raj Chhetri. Partial purification and characterisation of cytosolic Fructose-1, 6-bisphosphatase from Drymaria cordata. Annals of Plant Sciences 7.4 (2018) pp. 2126-2133.

do $\mathrm{http}: / / \mathrm{dx}$. doi.org/10.21746/aps.2018.7.4.9 